\title{
„Popular Stoicism”. A New Chance for Practical Philosophy or Mere Illusion?
}

\section{Tomasz Stefaniuk}

https://orcid.org/0000-0002-0009-3142

Can philosophy be of use in our over-commercialized culture? Is it still needed at all? Perhaps one of the ways to "keep philosophy going " (if it is not to remain merely an academic activity detached to a great extent from life) is to focus on teaching to live comfortably and wisely. Analyzed are some phenomena related to the social and cultural role of philosophy in modern times, especially so with reference to mass culture. Also reviewed are on-going attempts at bringing about the "rebirth" of Stoicism, understood primarily as practical philosophy. The author focuses on the "Polish philosophical market" and in particular on books written by present-day propagators of "pop-Stoicism" Marcin Fabjański and Tomasz Mazur, and their activities pursued outside the academic milieu. Could their publications and activities bring people closer to philosophy in general, and to Stoicism especially?

Keywords: Philosophy, practical philosophy, Stoicism, pop-Stoicism, popular Stoicism, Polish philosophy, ethics

We may ask ourselves whether philosophy is still needed at all; and if so, why, and how could it function today as a part of culture? In order to answer these types of questions we tend to focus on two contemporary tendencies. First of them is dominant modern scientism claiming that the real and fully justified knowledge

TOMASZ STEFANIUK, habilitated doctor, Institute of Philosophy, Maria Curie-Skłodowska University in Lublin, Poland; address for correspondence: Instytut Filozofii UMCS, Pl. Marii CurieSkłodowskiej 4, PL 20-031 Lublin; e-mail: tomasz.stefaniuk@umcs.pl 
of reality is provided only by the natural sciences ${ }^{2}$; and such a program makes philosophy of course less important. The second one is professionalization of philosophy distancing itself from the concerns of daily life ${ }^{3}$. In other words, it seems that at the beginning of the 21 st century no-one expects from philosophy that it will be an alternative to this image of the world which is offered by natural science, nor that philosophy could provide real knowledge or wisdom that would help to deal with the hardships of life.

Perhaps one of the possibilities of "preservation of philosophy” should be focusing on how it can teach to live beautifully and wisely, and how, thanks to this, achieve happiness. Undoubtedly, that was one of the ways of understanding philosophy in antiquity ${ }^{4}$, especially among those philosophers for whom ethical views were important. If that would be so, perhaps the news about the end of philosophy would be exaggerated. And if that were the case, philosophy could even play certain social role; or rather should it, in a sense by its nature, remain

\footnotetext{
${ }^{2}$ Cf., for instance, Isabelle Thomas-Fogiel, Death of Philosophy. Reference and Self-reference in Contemporary Thought (New York: Columbia University Press, 2011), 16-36. One of the most-known contemporary critics of philosophy, at least in its present form, is found in the book of Richard Rorty Philosophy and the Mirror of Nature, cf. Richard Rorty, Philosophy and the Mirror of Nature (New Jersey: Princeton University Press, 2009). The problem of the „end of philosophy in modern times” was also discussed by Martin Heidegger; cf. Martin Heidegger, The End of Philosophy, trans. Joan Stambaugh (Chicago: The University of Chicago Press, 2003). Some authors, on the other hand, like Brian Leiter, argues that idea that we have reached the „end of philosophy” is a „myth about philosophy”; cf. Brian Leiter, Introduction, in: The Future of Philosophy, ed. Brian Leiter (Oxford: Oxford University Press, 2004), 18.

${ }^{3}$ Cf., for instance, John Lachs, The Relevance of Philosophy to Life (Nashville-London: Vanderbilt University Press, 1995), XIII.

${ }^{4}$ As one may read in the Introduction to The Quest for the Good Life: Ancient Philosophers on Happiness, "ancient ethicists mostly agree in taking happiness to provide the highest good or ultimate end in human life [...]. Thus ancient ethics centered on the notion of happiness [...]. All - or most, at any rate - philosophers and philosophical schools agreed that happiness was the proper content of the good life. Cf. Øywind Rabbås et. al., eds., The Quest for the Good Life: Ancient Philosophers on Happiness (Oxford: Oxford University Press, 2015), 2. As J. M. Cooper writes, "in antiquity, beginning with Socrates, [...] philosophy was widely pursued as not just the best guide to life but as both the intellectual basis and the motivating force for the best human life. [...] Over most of the one thousand years of philosophy in ancient Greece and Rome, philosophy was assiduously studied in every generation $[\ldots]$ as the best way to become good people and to live good human lives." Cf. John M. Cooper, Pursuits of Wisdom: Six Ways of Life in Ancient Philosophy from Socrates to Plotinus (New Jersey: Princeton Univeristy Press, 2012), 2.
} 
a domain reserved merely for professionals, students and small groups of enthusiasts?

The purpose of this article is to analyze certain phenomenon related both to the social and cultural functioning of philosophy in modern times, as well as to analyze some current attempts to bring about the „rebirth” of Stoicism, understood primarily as practical philosophy ${ }^{5}$. Of course, similar attempts may be found at various periods of the history. We can mention, for instance, the Middle Ages and some attempts leading to generate interest in the Stoics' ethics by the first Arab philosopher, Al-Kindi (c. 801-873) ${ }^{6}$. The modern era can be mentioned as well, for example, the neo-Renaissance Stoicism, which was established by Justus Lipsius (1547-1606), author of the work entitled De Constantia ${ }^{7}$. Some Stoic ideas can be also found, for instance, in Descartes' and Spinoza's works ${ }^{8}$, but all that has already been well researched.

It is hard not to notice that contemporary attempts aiming at revival of Stoicism are considerably different from the earlier ones, only to mention ancient, medieval or early modern philosophies. This is because our present culture is something special, and it is due to a clear crisis of what is termed a high culture, as well as the dominant position of popular culture. The latter is sometimes called - mostly by its critics - mass culture and is usually accused of overcommercialization of culture or of making it shallow, as well as of manipulating mass society into passivity 9 . The functioning of mass culture - including the functioning of philosophy in such cultural reality - has led to the fact that certain

${ }^{5}$ Of course, there are no attempts to revive the natural philosophy of the ancient Stoics, or in other words, to revive Stoicism „in its entirety”, or as a complete system. This is due to the fact that natural philosophy of Stoicism has long lost its scientific value. Nowadays, only the ethics of the Stoics seem to be of interest.

${ }^{6}$ Cf. Peter S. Groff, "Al-Kindi and Nietzsche on the Stoic Art of Banishing Sorrow," The Journal of Nietzsche Studies 28, no. 1 (2004): 139-173.

${ }^{7}$ Cf., for instance, John Sellars, "Stoic Fate in Justus Lipsius's De Constantia and Physiologia Stoicorum," Journal of the History of Philosophy 52, no. 4 (2014): 653-674; Natasha Constantinidou, "Public and Private, Divine and Temporal in Justus Lipsius' De Constantia and Politica," Renaissance Studies 26, no. 3 (2012): 345-364.

${ }^{8}$ Cf. Derk Pereboom, "Stoic Psychotherapy in Descartes and Spinoza," Faith and Philosophy11, 11, no. 4 (1994): 592-625.

${ }^{9}$ Cf., for instance, Theodore Adorno, The Culture Industry: Selected Essays on Mass Culture (London-New York: Routledge, 2001); Dwight MacDonald, “A Theory of Mass Culture,” Diogenes 3, no. 1 (1953): 1-17. 
elements of culture can remain only if there is some sort of demand. In other words, contact between the originator of the new cultural "product" - for example an author of a philosophical work or a propagator of certain philosophy - and the „recipient» has been reduced (on such a „cultural market”) to the seller-buyer relationship. The "customer" here is also someone who expects to be offered a "product" that is tailored to his/hers needs. This is a completely new situation in history of human culture, given that philosophy has always been functioning within the boundaries of "cultural space” available only to certain elites; in other words it was usually understood as a part of high culture and something opposed to the culture of the masses ${ }^{10}$. And it was not a question of lowering the level of philosophical discourse for "ordinary people” what mattered, but rather attempting to "rise higher" those who aspired to be philosophers or, at least, aspired to be their readers or listeners. Under the current conditions of fully commercialized cultural creativity, anyone bringing something new in the field of culture - such as an artist or a philosopher - must first of all be interested in potential audiences, and that means he/she must find "buyers” or "customers"; and the more of these „costumers", the better.

When discussing the functioning of culture in modern times, it is also necessary to mention the IT revolution ${ }^{11}$ which, in a sense, is something already accomplished. We are not referring here to the fact that this revolution has stopped, because it is not the case, but rather to the fact that the changes that have been made in the material and cultural field, in a relatively short time, are already permanent; that means they are indelible in our world, or at least it seems so. This revolution has led to the situation in which, among other things, new means and technologies for communicating or for sharing information (information, though not always knowledge or wisdom), have enabled expressing one's own thoughts and opinions in a way unheard of in human history. Incredible and

${ }^{10}$ And it was so since the very beginnings of philosophy, taking into account, for example, the elitist views of Heraclitus of Ephesus.

${ }^{11}$ The term „IT revolution" is widely used and means the development of technologies such as computers and digital communication, which (in the second half of the twentieth century) has led to reduction in the cost of processing, storing and transmitting information in all forms, and to enormous popularization of these technologies as means of social communication. The term is used by many contemporary researchers; cf., for instance, Michael H. Harris, "Is the Revolution Now Over, Or Has It Just Begun? A Year of the Internet in Higher Education," The Internet and Higher Education 1, no. 4 (1999): 243-251. 
unprecedented perfection of such means and technologies, however, is not accompanied (at least not always) by high quality of the content delivered, the increase of general education or development of culture. It is not just this that the vast majority of information provided through the Internet, television or social networking sites has no importance (and sometimes also has no meaning); it is also „everyone talking about everything”, which may make some specialists in some fields becoming less popular then certain blog-sites hosts etc. Now it is easy to imagine that instead of an academic article, a blog of some dilettante, writing about the same as a genuine specialist, would be more popular and more referred to. It should not be surprising, therefore, that in such a cultural reality someone who wants to succeed in bringing about the revival of philosophy would try to gain more interest and be almost forced to present a "product" that is much simpler and more appropriate for the masses. In other words he/she will be aiming at blog readers, social network participants or merely at residents of growing cities, and the latter means people who are concentrated on their own careers, who love shopping and not always have much time for deeper reasoning or consideration. We have to deal, therefore, with the crisis of what is (or was) defined as high culture and, at the same time, with the dominant form of popular culture (or mass-culture) and over-commercializing of cultural and social life ${ }^{12}$. Such conditions are very unfavorable for the development and functioning of philosophy in the public sphere and in culture, broadly understood.

\section{„Popular Stoicism” and the praise of passivity}

For analyzing attempts aiming at revival of Stoicism as a practical philosophy (in Poland, in recent years) it seems proper to use terms like „popular Stoicism” or "pop-Stoicism”, meaning contemporary commercialized Stoicism or, to more precise, commercialized elements of Stoicism. By using such terms I would not like to completely ridicule or deprive any value of certain endeavors, which will be discussed and analyzed in the further part of the text. I just would like to point out two things. Firstly, some forms of cultural activity that are being discussed here clearly show the difficulties or constraints which must be faced by anyone

\footnotetext{
${ }^{12}$ Cf., for instance, Juliet Schor, Born to Buy: The Commercialized Child and the New Consumer Culture, (New York: Simon and Schuster, 2004).
} 
trying to get the public more interested in philosophy nowadays. Such a person might be taken as ridiculous, unless he/she decides to lower standards of philosophical discourse (or perhaps of philosophy itself) and would be willing to be active in certain socio-cultural realities, primarily related to the commercialization, or over-commercialization of culture (which was already mentioned), functioning of mass culture etc. When one is examining attempts aiming at the revival of Stoicism as a practical philosophy that is exactly the case.

Secondly, when we mention "pop-Stoicism” or the simplistic modern form of „commercialized Stoicism”, it is necessary to distinguish it from the Stoicism of ancient philosophers, that is, from the "proper” or „original” Stoicism, which has long been the subject of serious academic research and discussion ${ }^{13}$. Seeking the answer to the question of how to achieve happiness, the Stoics, like Socrates before them, proclaim the necessity of connecting happiness and virtue. According to them, it is because one should not seek happiness outside of man, that is in things; for this is the area of what is independent of man's will and actions, whereas human mind can be shaped and perfected. According to them, anyone who really values virtue becomes independent of all external circumstances. This belief has been combined in the ethics of the Stoics with a specific cult of rationalism and nature (in the widest possible meaning of this term). Life should first of all be compatible with the nature of man himself, and then with nature in general. In other words, to live virtuously and to live according to nature is - according to the Stoics - basically the same. Living in harmony with nature means also to compatible with reason, because it is not affections or passions, but just reason (or rationality) that determines human nature. This is a significant statement, because for the Stoics it means that reason should be considered as a measure of proper and moral conduct. Stoic's ethics also contained elements that were probably difficult to accept for the masses. Such elements were, for example, the postulate of radical self-development in order to coordinate one's behavior and one's expectations with the requirements of reason. The wise person, or the philosopher, should throw off all affections and passions, because none of them is natural and serve man; it is thus sort of apathy or indifference that characterizes the sage. One should be guided only by reason, and

${ }^{13}$ Cf., for instance, Stephen Engstrom and Jennifer Whiting, eds., Aristotle, Kant, and the Stoics: Rethinking Happiness and Duty (Cambridge: Cambridge University Press, 1998); Anthony Arthur Long, Stoic Studies (Berkeley: University of California Press, 1996). 
not, for example, by pity or sadness. The ethics of the Stoics called for severe seriousness in making decisions, as well as in defining our goals and aspirations, and certainly was not intended for the masses, but only for certain individuals who would be willing to answer Stoic call to follow the instructions of reason, as well as to reject common beliefs regarding feelings, affects and the emotional side of life.

It must also be stressed at the outset that contemporary „pop-Stoicism” is not particularly interesting because of its new content (since it basically does not proclaim anything other than what was presented in the ancient era), but merely simplifies "inherited ideas" and strives to make it more acceptable from the point of view of today's ovcer-commercialized culture, or mass culture. „Pop-Stoicism” is rather interesting social and cultural phenomenon, and it should be understood as relatively short-lived and substantially extinct, at least in relation to the „Polish philosophical market”, or „Polish cultural market”. At the same time it seems that it was not able to leave behind any major, significant trace, though now it might be of interest to a historian of philosophy, or to a researcher of changes in contemporary culture. The term "pop-Stoicism” may, however, be somewhat misleading, as it may suggest that we are dealing with a school of philosophy, and yet it is not. This term means different forms of activity - usually related to the publication of books or articles, as well as public speeches, and thus to the introduction of Stoicism into the reality of commercialized culture and the contemporary consumer society, overwhelmed by information - but not a school of philosophy, in classical meaning, because such a school simply is and was not.

In addition, attempts leading to describe and analyze this and similar phenomena are perhaps exposed to certain difficulties, because the propagators of „pop-Stoicism” are, at least in some cases, persons with certain academic record and ranks. Here, however, I do not attribute myself the right to review their academic achievements (which undoubtedly has been done), but I rather intend to describe and analyze the activities involved in attempting to popularize certain „simplified version" of philosophy; I mean, therefore, the analysis of their nonacademic activities, as well as analysis of social and cultural functions of such activities.

One of the elements of what have been described here as "popular Stoicism” is publishing. We should mention here, among others, the book of one of the most important Polish propagators of „pop-Stoicism”, Marcin Fabjański, entitled 
Stoicyzm uliczny. Jak oswajać trudne sytuacje [= Street Stoicism. How to Tame Difficult Situations ${ }^{14}$. This is quite an interesting book, but not because it presents any valuable philosophy of life that could be recommended or promoted; on the contrary, such philosophy as presented therein does not seem to be good for man in the practice of everyday life, which I will try to show briefly in the further part of these considerations. And it is not so because of the presentation of Stoicism, for the above-mentioned book discuses essential elements of Stoicism quite inadequately, to which I will also return. But Fabjański's book seems interesting as an attempt (in my opinion unsuccessful, but still, an attempt) to create a kind of „popular philosophy” or "pop-philosophy”, if one may use such terms. It would be a philosophy, or perhaps a "philosophy", so simple that making oneself acquainted with it would take relatively little time and would not be particularly engaging. Such „pop-philosophy” would be another "product” effectively functioning (at least potentially) in the realm of modern over-commercialized culture.

The publication of the above-mentioned book by Fabjański in the year 2010 made the author became famous (to the extent that it is possible to become famous while propagating certain philosophical ideas nowadays); he was invited to the press and radio, interviewed and so on. The book was well received, at least initially. One has to admit that the book itself has an interesting layout, namely, it presents forty one - as Fabjański himself puts it - „street situations”. These are the situations connected with life and functioning in a big city, and the titles of the book's chapters (for example Impolite Saleswoman, Noise Behind the Wall, Computer's Hang, Too Much to Do, Friend's New Porsche, Advances Rejected, Reprimand from the Boss, Lost Keys and so on) are explicitly corresponding to such situations.

Such titles clearly correspond with the content of the book itself: everyday, "uncomfortable" situations experienced by a large city resident, already mature and having a job, probably in a corporation. In any case, it is not a lack of a job or money that makes a problem here; rather it is not dealing with the difficulties of life, which is caused (as the author suggests, completely in concordance with the philosophy of the Stoics) by the wrong approach of the person concerned. In other words, problems related to one's functioning in the world are his/her own internal

\footnotetext{
${ }^{14}$ Marcin Fabjański, Stoicyzm uliczny. Jak oswajać trudne sytuacje (Warszawa: Wydawnictwo Czarna Owca, 2010). The book was published only in Polish.
} 
problems, or to be more precise, they are problems of the mind. And this means, according to the philosophy of the Stoics, that if one chooses to either strive to change the whole world or to change oneself, only the latter makes sense. It is worth noting, by the way, that not only the main concept is interesting, but also its realization. Each chapter of Fabjański's book is divided into four parts: at first, there is a brief description of some uncomfortable situation, for example, an above-mentioned reprimand from the boss. Then, for such a situation a philosophical sentence is given. Then there is the discussion of the sentence or, in other words, the author presents his comment. Lastly, there is a "taming of the situation", which means explaining how we should cope with a given situation, which usually leads to gaining a „new consciousness"15.

Street Stoicism - as well as other, similar publications - can actually be treated as a textbook of practical philosophy by a reader so far unfamiliar with philosophy, or by someone not so well acquainted with it; that is, for example, by the average citizen of a modern metropolis, someone dealing well with a career, earning and spending money etc., though not necessarily coping with stress and certain nervous situations. Such a reader may be satisfied and conclude that adherence to "Stoic philosophy"16 can really alter his mind and tame difficult situations of everyday life. And here we can clearly see how Fabjański's „popStoicism" would differ from the "genuine”, historical Stoicism. While the latter, in a sense by definition, was not a philosophy for the masses, and sought to create a "new man" - that is a true rationalist, very consistent in his decisions and actions, strongly rejecting everything that was not in concordance with philosophical reason - „pop-Stoicism” is precisely a proposition for the masses. In other words, historical Stoicism was something very elitist, while „popStoicism” (and probably every form of "pop-philosophy”) is a clearly egalitarian proposition, moreover, a proposition aimed at a mass audience. This is, at the same time, a proposition for all those who are willing not only to pay for the book but also, possibly, for taking part in sort of further training or coaching, which would make a participant a little bit more reconciled to the eventual failures and hardships of living in our modern, consumer reality. „Pop-Stoicism” is not, therefore, a great call to „re-making man”, aimed at those outstanding individuals

${ }^{15}$ Cf., for instance, ibid., 30-133.

${ }^{16}$ As I will later discuss more thoroughly, such a philosophical advice is not entirely of Stoic origin. 
who would be brave and consistent enough to follow the directions of reason. It is rather a kind of "the-rapy" (one could write therapy, without the quotation marks, if it was proven that it can really bring proper results), or a form of coaching that has a reference to a specific, "historical” school of philosophy in the name.

Such publications may in fact serve as an incentive for a further, more serious encounter with philosophy. It would, however, be a mistake to think that through such books a reader could know Stoicism better; because it is not exactly Stoicism that is to be found inside, rather we are dealing here with a kind of "patchwork" of ideas. By introducing the antidote to the troublesome situations of everyday life, the author presents not only Stoic phrases (taken, for example, from Marcus Aurelius, Seneca or Epictetus), but also the thoughts of Epicurus, Ajahn Chah (a twentieth-century Buddhist monk), Anaxagoras (who was a Pre-Socratric, and thus could not be a Stoic), the Chinese thinker Laozi (also known as Lao-Tzu, the founder of Taoism), as well as certain modern German philosophers, Nietzsche and Schopenhauer. Besides, Fabjański refers to irrational argumentation, recalling some Buddhist stories or legends. In general, one can get the impression that the author is particularly close to Buddhism, as he often writes "use the Buddha's formula" 17 or "apply variant of Buddhist meditation of mindfulness"18 and the like. So it is puzzling why this philosophical or rather pseudo-philosophical patchwork of ideas is accompanied by the label of Stoicism, and not, for example, of Buddhism. Probably just as „street Stoicism” the author's position could be defined as, for example, „Occidentalized Buddhism” or „street Buddhism". The author may be exposed to the criticism, for the Buddha's formulas are to be found in a book which title speaks of Stoicism; perhaps it is unnecessary to mislead the reader.

Such an idea for a syncretic, practical quasi-philosophy can raise some concern; and this is due to the fact that if one wants to present himself as a specialist in Buddhism, Stoicism and other schools of Ancient Greek Philosophy, as well as Modern German philosophy, a question comes whether he/she really has became well acquainted with these fields of study. Perhaps these philosophies have been dealt with in a rather arbitrary and selective way; and thus, perhaps, Fabjański will make of his readers and listeners, at most, „shallow Stoics”,

\footnotetext{
${ }^{17}$ Cf., for instance, Fabjański, 97.

${ }^{18}$ Cf. ibid., 129.
} 
„shallow Buddhists”, „shallow Western philosophy adherents” and so on? And this is probably a well founded concern because, for example, a closer study of the philosophy of Nietzsche (proclaiming the cult of a strong and active human entity, not bound by any moral doctrine, at least in the traditional sense) leads to a conclusion that it is the complete opposite of Schopenhauer's (or Buddhist) ethics with its quietism. They are, therefore, the philosophies which, if taken as certain wholes, cannot be combined. It is just the same with Epicurean ethics and hedonism, which is, in essence, the opposite of the ethics of the Stoics who were calling to the great inner transformation of man, to the rejection of the pleasures followed by the crowd and so on. In other words, it seems impossible to reasonably combine the elements of Nietzsche's and Schopenhauer's philosophies with each other, and also with Stoicism and Epicureanism. Moreover, it can be considered unreasonable or even ridiculous by those who have become better acquainted with the history of human thought. Those were - and should remain - separate systems of thinking. And their value probably lies in the fact that they are different from each other, not similar.

\section{Stoic techniques and art of tea making}

It seems that the practical philosophy presented by Fabjański - which is largely inspired by Stoicism but also, as has been pointed out, by Buddhism - has its weaknesses. This is, in my opinion, related to the justification and promotion of passiveness in life. For example, in the above-mentioned book we read: „If it were otherwise, it would have been different. [...] Do not fight the flow of life, flow with it"19. One might say that this is a very unreasonable and even harmful philosophy; if something really bad happens to my loved ones or to myself should I really agree on the course of events? Also, should not I be ambitious and rather struggle with obstacles to achieve something better? For example, if my child is ill, should I really "go with the flow" and not go to the doctor, nor try to get the best treatment? In another passage the author writes: „Remember: if something is difficult to obtain, it is unnecessary"20. Well, in my opinion this is a bad advice. For example, if it is difficult to finish medical studies (and it is certainly easier to

\footnotetext{
${ }^{19}$ Cf. ibid., 16-17.

${ }^{20}$ Cf. ibid., 45.
} 
fail to complete such studies than to finish them), either to obtain a professor's title or to create an outstanding work of art, should we not do it because it is difficult and requires some discipline and effort? And if we had succeeded, was it really unne-cessary? It seems rather that it is better to struggle with oneself and with the adversity of the fate, and to "throw" - as would be said by, for example, Jean-Paul Sartre - certain projects into our future. Passivity, concerned as certain life pattern, does not need to be promoted, as opposed to activity. On the one hand, this element of "pop-Stoicism” propagated by Fabjański somehow corresponds to the Stoicism of ancient philosophers, who were really interested in not changing the world, but rather in changing the man, or more precisely, his mind. On the other hand, however, their ethics and anthropology assumed that one could not become the perfect man without great effort contributing to his development; the effort associated with self-improvement is therefore assumed in "original”, historical Stoicism. In relation to what Fabjański writes, it is possible to raise the objection that the author has not got himself well acquainted with Stoicism, studied it shallowly or that he has chosen only certain elements of Stoic's though, matching them to a sort of preconceived notion.

The accusation of a certain kind of shallowness or naivety can also be referred to the "techniques”, which are presented and discussed by the practicing Stoic, Fabjański, in his book. Such "techniques" should help, in his opinion, to deal with a stressful reality. The author writes, among other things, about „re-labeling”, that is, naming or defining something anew (which could be also called „rationalizing things"). This is a well-known psychological mechanism, without which, by the way, it would be probably be much more difficult for people to function. If something does not work out, or if anything bad happens, and one cannot repel it, he/she is starting to look for some kind of justification, in other words, is trying to find something positive (at least to some extent) in bad situations. However, there are some limitations of such „technique”. Namely, for example, if I would be dying of some kind of incurable disease, should I just - as Fabjański argues "change my attitude" and "accept what is positive in this experience"21? After all, are there positive aspects in all kinds of life experiences? Probably in such a situation a strictly religious perspective can offer greater consolation and help, because death is thought of as only transition to a better world. In other words, it

\footnotetext{
${ }^{21}$ Cf. ibid., 65.
} 
seems impossible to rationalize - in the fashion of Stoic philosophy or supporters of "pop-Stoicism” - absolutely all the troubles and sorrows of human existence. One could say, therefore, that such "philosophical therapy" is quite limited and will not be effective in every situation.

Terms such as „re-labeling” or another, „TRI” (from: true, relevant, important $)^{22}$ will certainly make an impression on people who are rather poorly acquainted with philosophy, or with psychotherapy, broadly understood. This is something that can properly encourage the "consumer", ready to buy or to pay for something, or at least to make him more interested in a "product” (in this case the product is a recipe for happy, careless life). It is important to note that not all of the "therapeutic techniques”, however, are neologisms. For example, the author mentions reflection (in a specific, Stoic sense), which means treating what someone is currently doing as an exciting adventure ${ }^{23}$. As for the "re-labeling” method, there are some reasonable doubts, too. Could it really be applicable in every situation; is it actually effective? It is difficult to imagine that, for example, an extremely suffering person, or even someone with a very exhausting job, would be able to deal with such a situation as with an „exciting adventure”. For example, the author gives advice to play even the role of a beggar masterly $y^{24}$ That may be only the point of view of someone who has never been really hungry, or in jeopardy. A real beggar would be only interested in surviving, gaining food and so on, and not in "playing roles”. Role playing cannot be of interest to anyone who is in danger, in life threatening situation etc. Similarly, the author gives advice to play your role well even during the funeral, by spreading happiness around. It seems, however, that if someone „spreads happiness around" during the funeral, then probably the deceased was not close to him. That may also mean that such a person is possibly ill-mannered and unable to keep himself in certain situations. If anyone is not suffering from a loss at all, then it probably was not a loss, or that loss meant little to us.

Critical remarks can be made not only on "therapeutic methods”. It seems, for example, that "pop-Stoicism” is sometimes accompanied (and this is, in my opinion, poorly concealed) by sort of complex of superiority, and perhaps also by

${ }^{22}$ In short, this technique involves asking yourself certain questions what leads to „internal control of the problem"; cf. ibid., 117.

${ }^{23}$ Cf. ibid., 89.

${ }^{24}$ Cf. ibid., 109. 
lack of ordinary human liking for other people. In his book, Fabjański writes that Ivan Pavlov could formulate his discoveries by examining certain people instead of $\operatorname{dogs}^{25}$. In another passage he argues that the Stoic caught in the car, in the traffic jam, should look at other people more or less as we look at the animals in the $\mathrm{zoo}^{26}$. Besides, the author is sometimes lacking in basic knowledge. For example, in one of the chapters there is someone worried about what would happen if a car was struck by lightning ${ }^{27}$. Well, nothing would happen unless it was a convertible, because the car's body works in such a case as Faraday's cage: electric charges would pass through it and nothing would happen to a human inside. So it is not a real problem, or a threat, but a pseudo-problem.

Fabjański encourages to Stoicism, or rather to „pop-stoicism”, not only through his publications, but also through meeting with his listeners, giving lectures and so on ${ }^{28}$. He ran, for instance, courses for managers, practical Stoic philosophy workshops and Buddhist retreat meetings (not for free, of course) ${ }^{29}$. The offer of Alcha. Personal Development Center, where Fabianski, as one of many, once ran workshops, is also worth mentioning. From the website of the Center we learn that the last time his workshop entitled Street Stoicism was ran in $2013^{30}$. In addition to that the above-mentioned Center for spiritual development offered, among other things, the following workshops: Urasenke Style Tea Shop, Traditional Singing Workshop, Chinese Medicine, Find Your Color: Aesthetic Workshop, Thai Massage, Ayurvedic Cooking, Hormonal Yoga, Chinese Tea Tradition and Belly Dance. I do not intend to depreciate (at least not entirely) that type of courses, nor active participation of someone with doctor's degree, but it is easy to see that here we are simply dealing with a commercial activity addressed to a rather bored resident of a big city who has some money to

${ }^{25}$ Cf. ibid., 29.
${ }^{26}$ Cf. ibid., 69.
${ }^{27}$ Cf. ibid., 14.
${ }^{28}$ This article is not intended to cover all manifestations of this type of activity (i.e. meetings, lectures, presentations etc.). Here I only give some examples of such activity of Polish propagators of „pop-Stoicism”.

29 https://mahajana.net/aktualnosci/odosobnienie-z-dr-marcinem-fabjanskim (accessed 19 October, 2017).

30 http://www.alcha.pl/osoby-prowadzace-zajecia/marcin-fabjanski (accessed 19 October, 2017). The fee for participation in the workshop, as stated in the said site, is 480 PLN, without accommodation and meals. The bank account number is displayed immediately. 
spend and would like to "taste something new". On the other hand, placing "spiritual exercises”, taken form Seneca or Marcus Aurelius, along with belly dance and hormonal yoga can raise some concern. Undoubtedly, this may be taken as deprecation of Stoicism, to a degree, and maybe even as depreciation of philosophy itself.

\section{Between non-serious and more serious Stoicism}

The allegation on rather frivolous attitude towards philosophy cannot be made with regard to another Polish propagator of Stoicism (or rather "popStoicism"), who has been also active outside academia, Tomasz Mazur ${ }^{31}$. His (as well as other members' of the Center for Stoic Practices ${ }^{32}$ ) activities, compared with Fabjański's, has probably a little bit more to do with the historical Stoicism. On the website of the Center we read, among other things, that it aims at reactivating the Stoic tradition in the fullest possible form, both in practical and theoretical terms. On the other hand, the Center intends to adopt Stoicism to the contemporary state of knowledge, language and needs. It would be therefore, according to the propagators of the Center for Stoic Practices, not so much Stoicism as post-Stoicism. Post-Stoicism, as we read on their website, is based on the legacy of ancient Stoicism, but enriches it with new achievements in science, neuroscience and psychology. It also differs from its antique pattern in that it does not claim to be the only right way, and accepts other possible philosophies of life and hierarchies of values. In other words, post-Stoicism recognizes and develops one option of human nature, not rejecting definitively others. During the workshops, participants practice Stoic exercises, such as, for example, praemeditatio malorum (foretelling misery and writing sort of black scenarios for oneself, an exercise taken from Epictetus) or „cosmic perspective”. The latter is to distance ourselves as far as possible from the situation in which we are. If one looks at the problems from the perspective of the cosmos, he/she will be microscopic and insignificant in comparison to the vastness of the universe.

${ }^{31}$ As in the case of Fabjański, I am not going to discuss all of Mazur's non-academic activities aimed at popularization of Stoicism, but only to give some examples of such activity.

${ }^{32} \mathrm{http}: / /$ centrumpraktykistoickiej.pl (accessed 19 October, 2017). 
It seems that the driving force of the Center is Mazur who is undoubtedly an interesting figure, for some inspirational, for others probably controversial. As he writes on his website, a modern man, when confronted with the spiritual crisis of our time, eagerly refers to the teachings of "trendy" Eastern religious or philosophical traditions; yet our own Western culture also has an interesting „spiritual offer” of which we rarely make use, for example Stoicism ${ }^{33}$. Mazur asks an interesting and important question: why instead of Buddhism or yoga we do not practice Stoicism today? Perhaps it is so - he replies to the above question, with a lot of reason - because today there are no practicing Stoic masters who can teach and give advice, while there are Buddhists and yogis ${ }^{34}$. It is worthy to notice, by the way, that similar opinion was expressed previously in 2005 Pierre Hadot's article entitled There Are Nowadays Professors of Philosophy, but not Philosophers $^{35}$. Thus Mazur's attempt to explain why Stoicism as a practical philosophy is relatively not popular nowadays, in the West, is not something particularly original, except in relation to the area of Polish culture and Polish philosophy.

Mazur, in addition to his academic work, decided to practice philosophy in the most basic sense of the word, and this means to practice it as the ancient philosophers did. In other words, he decided to be a mentor, or master of philosophy, and therefore not to actively participate only in academic discourse, but also in the „art of life”. This means playing the social role of a „modern sage” to whom the others come for advice. Such a role is fulfilled, as it seems, effectively, because for a few years there has been a small group of Stoic enthusiasts who want to carry out in practice what Seneca and Epicetus were calling for, and they are associated with the above-mentioned Center, where Mazur seems to be the most important figure. Mazur describes himself as a "contemporary practicing Stoic"36. Such words probably show his strong self-confidence, but his position is not significantly far from the truth when we consider how great value for the ancient philosophers was to fulfill in practice their ideas and views ${ }^{37}$. It should be noted,

\footnotetext{
${ }^{33} \mathrm{http} / / /$ www.tomaszmazur.edu.pl/biogram (accessed 19 October, 2017).

${ }^{34}$ Cf. bid..

${ }^{35}$ Cf. Pierre Hadot, "There Are Nowadays Professors of Philosophy, but not Philosophers," The
} Journal of Speculative Philosophy. New Series 19, no. 3 (2005): 229-237.

${ }^{36} \mathrm{http} / / /$ www.tomaszmazur.edu.pl/stoicyzm/moja-droga-do-stoicyzmu (accessed 19 October, 2017).

${ }^{37}$ The fees are not listed on the site. 
however, that Mazur only adopts their philosophy to the requirements of modern times. These requirements - as it is easy to notice when we visit one of his websites $^{38}$ - are related to the functioning in an extremely commercialized culture. For example, on such websites one may find the section For Companies, where he proposes his philosophical-Stoic workshops (including work on stress, work on his own goals and values etc.) and motivational speeches. True, prices are not listed there, but it is not hard to notice that the ideals of ancient philosophers such as Socrates or Diogenes of Sinope (who was, sometimes in the extremely outrageous way, neglecting money and material goods) have been, in relation to certain spheres of life, left far behind.

However, Mazur does not propagate „post-Stoicism” exclusively through lecturing and conducting workshops. He is also the author of several books, including Fiasko. Podręcznik nieudanej egzystencji [= Fiasco. The Book of Unsuccessful Existence $]^{39}$, ironic life anti-guidebook, publication of which was met with considerable interest by readers, and $O$ stawaniu się stoikiem. Czy jesteście gotowi na sukces? [= About Becoming A Stoic. Are You Ready for Success? ${ }^{40}$; both books have been published in Polish only.

The second of these publications presents the life of Eric, a "middle-aged

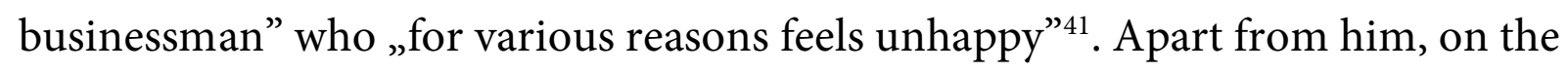
pages of the book we also meet other characters: his wife, two sons, daughter, relatives, as well as his friends and acquaintances. As we read, ,after looking for many other solutions, without a clear result, Eric has decided to give Stoicism a try" ${ }^{42}$. The phrase "to give Stoicism a try” is, as it seems, crucial here. Stoicism is one of the proposals that a bored and sometimes irritable citizen of a big city, successful in many areas beyond spiritual or intellectual development, can take advantage of.

This book is divided into three parts. The first one presents some kind of a starting point, that is Eric's life before the coming change. In this part the author of the book, along with Eric, ponders what happiness is, what we want from

\footnotetext{
${ }^{38} \mathrm{http}: / /$ stoicway.net/oferta-dla-firm (accessed 19 October, 2017).

${ }^{39}$ Tomasz Mazur, Fiasko. Podręcznik nieudanej egzystencji (Warszawa: Wydawnictwo Carta Blanca, 2012).

${ }^{40} \mathrm{Id}$., O stawaniu się stoikiem. Czy jesteście gotowi na sukces?(Warszawa: PWN, 2014).

${ }^{41}$ Ibid., 9.

${ }^{42}$ Ibid.
} 
people, what other people want from us, and so on. The second part contains Stoic exercises in practice or, as Mazur himself writes, „exercises and strategies by which we can work tirelessly for internal transformation"43. Here, Stoic exercises are accompanied by scenarios of their realization, as well as discussion of desirable and undesirable effects of their application ${ }^{44}$. Eric (as well as readers of the book) learns, for example, how to deal with the lack of professional fulfillment, threat of financial troubles, heartbreak, fear of losing loved ones or illness. His observations allow us to point out that the author, first of all, tries to present a practical path leading to becoming a modern Stoic; and Stoicism itself is pictured here in a very functional way. The third part of the book presents more advanced Stoic exercises which should strengthen the Stoic spirit by, among other, developing an appropriate hierarchy of values, interior preparation for troubles of life or perfection of one's mind ${ }^{45}$.

Analysis of the content of the discussed books, written by Fabjański and Mazur, as well as taking into account reason they have been written and published for, leads to the conclusion that it is not an original work. This is because the following books by Pierre Hadot: Philosophy as a Way of Life: Spiritual Exercises from Socrates to Foucault ${ }^{46}$ and What is Ancient Philosophy? ${ }^{47}$ were simply released earlier. In his books Hadot argues that philosophy for the ancient Greeks was not only a theory, but a life-long practice. A similar approach is presented by his Polish, lesser known colleagues, who wrote later. William B. Irvine, author of A Guide to the Good Life: The Ancient Art of Stoic Joy is writing the same ${ }^{48}$ as Hadot, however in his book this author pays relatively little attention to the history of Stoicism, and much more to spiritual exercises. In their books Mazur and Fabjański show a similar approach, and sometimes they even mention Hadot. It does not appear, therefore, that their writing should be regarded as something particularly original, unless with regard to the Polish publishing market.

\section{${ }^{43}$ Ibid., 12.}

${ }^{44}$ Cf. ibid.

${ }^{45}$ Cf. ibid., 101-102, 195-200, 248-255.

${ }^{46}$ Pierre Hadot, Philosophy as a Way of Life: Spiritual Exercises from Socrates to Foucault (Oxford: Blackweel, 1995).

${ }^{47}$ Id., What is Ancient Philosophy (Cambridge Mass.-London: The Belknap Press of Harvard University Press, 2002).

${ }^{48}$ William B. Irvine, A Guide to the Good Life: The Ancient Art of Stoic Joy (Oxford: Oxford University Press, 2009). 
This lack of originality did not stand in the way for above-mentioned propagators of "modern Stoicism” to become some sort of „personalities” appearing in the mass media. At the time they both gave interviews in the press, radio and television. Among other things, Mazur gave an interview to the Polish Radio One ${ }^{49}$, he also appeared on quite popular Radio Three Channel Club ${ }^{50}$ and was interviewed in 2014 in the magazine "Polityka" ${ }^{1}$. Such a relatively high interest in the media can be explained by the fact that in relation to the Polish „cultural market” these were quite fresh proposals. In addition to Mazur and Fabjański, other propagators of „modern Stoicism” appeared, for example, Piotr Stankiewicz, the author of book entitled Sztuka życia według stoików (The Art of Life According to Stoics), which presents about twenty exercises, supplemented by quotations from the classics of Stoicism ${ }^{52}$. Referring to the popularity of popStoicism in mass media, however, it should be emphasized that it was just some kind of momentary „media fashion”, a sort of curiosity that is already passed.

\section{Conclusion}

Considering attempts aiming at return to Stoicism as practical philosophy it is worth paying special attention to Mazur's books, as well as to „modern-Stoic workshops", conducted by the Center for Stoic Practice. These publications and activities did not bring great financial success (perhaps against expectations), but on the other hand they made practical philosophy a little bit more popular on the Polish „cultural market”, at least in a certain period of time. The fact that outside of academia there have been some philosophical disputes and philosophy in such a way has come out to „ordinary people” should be considered valuable. It seems that other attempts to popularize the philosophy of Stoicism outside the academic circles were not particularly effective. Mazur undoubtedly managed to arouse interest in philosophy, at least to some extent, in circles so far uninterested. Also,

\footnotetext{
${ }^{49} \mathrm{http} / / /$ www.polskieradio.pl/7/3068/Artykul/1124930,Stoicki-spokoj-recepta-na-trudne-czasy (accessed 23 October, 2017).

50 http://www.polskieradio.pl/9/396/Artykul/1089359,Skuteczny-stoicyzm (accessed 23 October, 2017).

${ }^{51} \mathrm{http}: / /$ www.polityka.pl/jamyoni/1594523,1,czy-w-dobie-internetu-mozna-byc-stoikiem.read (accessed 23 October, 2017).

${ }^{52}$ Piotr Stankiewicz, Sztuka życia według stoików (Warszawa: Wydawnictwo W.A.B., 2014).
} 
some of his books have explicitly propedeutical functions, which is also valuable. They encourage further exploration of philosophy, and especially of Stoicism thanks, among other things, to the author's choice of "golden thoughts" by Marcus Aurelius, Epicetus or Seneca. Such books should be primarily read by people who have not got a closer contact with philosophy yet, such as high school students (the more one may find some anecdotes and comics inside, sometimes really funny). On the other hand, for the reader who is a little more advanced in the knowledge of philosophy, such publications may be something trivial and even infantile.

These types of projects, appearing in the publishing market and in the broadly understood "educational space”, do not mean, however, that we could experience the rebirth of Stoicism as a contemporary practical philosophy; and this, in my opinion, involves two basic issues. First, by analyzing the content proclaimed either in the form of publications or in the form of proposed „spiritual development" courses, it can be seen that they are not always the same as Stoicism. For them Stoicism is, perhaps, the most important „component” of the presented views or "therapeutic” techniques. They often are syncretic, and more specifically, they tend to merge Stoicism with Buddhism or modern Western philosophy. This remark applies particularly to Fabjański's activities. In addition, it is difficult to talk about any major social response. Let us point to the fact that at the meetings organized by the Center for Stoic Practice there were usually only about twenty participants, or not much more, and the activity itself did not go far beyond certain café. The originators of such activities undoubtedly had greater ambition, but these failed to materialize. Ultimately, the attempts to revive Stoicism as a contemporary practical philosophy, which began around 2010, have resulted in several interesting publications, Stoic workshops and a number of interviews with „modern Stoics” in the press, on the radio and television.

The attempts discussed here should not be completely depreciated however. Moreover, it seems that it is good that in our commercialized culture there is room for attitudes focused on the search for the meaning of life. Unfortunately, the proposals coming from „contemporary Stoics” do not completely oppose such a commercialized cultural reality, and they even try to co-operate with it. It is perhaps the biggest objection that can be directed towards certain modern Stoics, or perhaps "Stoics"; especially if one is aware of how the activities of their ancient counterparts looked like. Contemporary Stoic courses, even if not very effective, 
are definitely positioned within commercial activities. Moreover, the advertising and bank account numbers - to which the charges for „learning Stoicism” should be transferred - in some cases allow us to think that it is only commercial activity. It seems that these proposals are addressed to such people who can do well in life, primarily in the professional and financial sense, and who would willingly spend a certain amount of money on „Stoic philosophy course”. „Contemporary Stoics” - contrary to their counterparts of antiquity - would not be, therefore, aiming at "creating a new man" (totally independent of the external world with its wealth and glamour), but rather at making contemporary man somehow slightly changed. Thus, perhaps paradoxically, the activities of the propagators of Modern "pop-Stoicism" are much more strongly associated with the work and attitude of the ancient sophists than with the attitude represented by Socrates, or the Cynics, who after all were (at least initially) the point of reference for Stoics. Like the sophists, propagators of "pop-Stoicism” treat their pedagogical mission in terms of profit, offering knowledge to everyone who would pay for it. The attitude (and perhaps spirituality) of Socrates and the Stoics of antiquity, when it comes to the activities of modern "Stoic masters”, is something they are probably far away from. Socrates - the "perfect sage” who met with people merely for a common understanding of the truth, and was discussing with them for their good and not for profit - was one of the most inspirational figures, at least when it comes to ancient philosophers. Besides, Socrates himself - as opposed to the sophists or other professional teachers, ready to find themselves well fit in more or less commercialized reality - probably would not be able to function in modern culture. And he undoubtedly would not want to turn philosophy, ethics or intellectual development of man into banality. And banality seems to be one of the essential features of contemporary mass culture or pop-culture, even if within this culture some courses are organized with the word "philosophy" in the name.

\section{References}

Adorno, Theodor. The Culture Industry: Selected Essays on Mass Culture. London-New York: Routledge, 2001.

Constantinidou, Natasha. "Public and Private, Divine and Temporal in Justus Lipsius' De Constantia and Politica." Renaissance Studies 26, no. 3 (2012): 345-364. 
Pobrane z czasopisma http://kulturaiwartosci.journals.umcs.pl

Cooper, John M. Pursuits of Wisdom: Six Ways of Life in Ancient Philosophy from Socrates to Plotinus. New Jersey: Princeton University Press, 2012.

Derk, Pereboom. "Stoic Psychotherapy in Descartes and Spinoza." Faith and Philosophy11, no. 4 (1994): 592-625.

Engstrom, Stephen and Jennifer Whiting, eds., Aristotle, Kant, and the Stoics: Rethinking Happiness and Duty. Cambridge: Cambridge University Press, 1998.

Fabjański, Marcin. Stoicyzm uliczny. Jak oswajać trudne sytuacje. Warszawa: Wydawnictwo Czarna Owca, 2010.

Groff, Peter S. “Al-Kindi and Nietzsche on the Stoic Art of Banishing Sorrow.” The Journal of Nietzsche Studies 28, no. 1 (2004): 139-173.

Hadot, Pierre. "There Are Nowadays Professors of Philosophy, but not Philosophers." The Journal of Speculative Philosophy. New Series 19, no. 3 (2005): 229-237.

Hadot, Pierre. Philosophy as a Way of Life: Spiritual Exercises from Socrates to Foucault. Oxford: Blackweel, 1995.

Hadot, Pierre. What is Ancient Philosophy. Cambridge Mass.-London: The Belknap Press of Harvard University Press, 2002.

Harris, Michael H. "Is the Revolution Now Over, Or Has It Just Begun? A Year of the Internet in Higher Education.” The Internet and Higher Education 1, no. 4 (1999): 243-251.

Heidegger, Martin. The End of Philosophy. Translated by Joan Stambaugh. Chicago: The University of Chicago Press, 2003.

Irvine, William B. A Guide to the Good Life: The Ancient Art of Stoic Joy. Oxford: Oxford University Press, 2009.

Lachs, John. The Relevance of Philosophy to Life. Nashville-London: Vanderbilt University Press, 1995.

Leiter, Brian. "Introduction.” In The Future of Philosophy, edited by Brian Leiter, 1-23. Oxford: Oxford University Press, 2004.

Long, Anthony Arthur. Stoic Studies. Berkeley: University of California Press, 1996.

MacDonald, Dwight. “A Theory of Mass Culture.” Diogenes 3, no. 1 (1953): 1-17.

Mazur, Tomasz. Fiasko. Podręcznik nieudanej egzystencji. Warszawa: Wydawnictwo Carta Blanca, 2012.

Mazur, Tomasz. O stawaniu się stoikiem. Czy jesteście gotowi na sukces?. Warszawa: PWN, 2014.

Schor, Juliet. Born to Buy: The Commercialized Child and the New Consumer Culture. New York: Simon and Schuster, 2004.

Sellars, John. "Stoic Fate in Justus Lipsius`s De Constantia and Physiologia Stoicorum." Journal of the History of Philosophy 52, no. 4, (2014): 653-674.

Stankiewicz, Piotr. Sztuka życia według stoików. Warszawa: Wydawnictwo W.A.B., 2014.

Thomas-Fogiel, Isabelle. The Death of Philosophy: Reference and Self-reference in Contemporary Thought. Columbia: Columbia University Press, 2011. 
Pobrane z czasopisma http://kulturaiwartosci.journals.umcs.pl

Øywind, Rabbås, Eyjólfur Kjalar Emilsson, Hallvard Fossheim, and Miira Tuominen, eds. Quest for the Good Life: Ancient Philosophers on Happiness. Oxford: Oxford University Press, 2015.

Rorty, Richard. Philosophy and the Mirror of Nature. New Jersey: Princeton University Press, 2009.

\section{Streszczenie}

Stoicyzm popularny. Nowa szansa dla filozofii praktycznej czy raczej iluzja?

Czy filozofia może funkcjonować w naszej nadmiernie skomercjalizowanej kulturze? Czy nadal jest potrzebna? Być może jedną z możliwości „przetrwania filozofii” - o ile nie chcemy, aby była to w dużej mierze oderwana od życia działalność akademicka - jest skoncentrowanie się na tym, jak pięknie i mądrze żyć? Celem tego artykułu jest analiza pewnych zjawisk związanych ze społecznym i kulturowym funkcjonowaniem filozofii we współczesnych czasach, szczególnie w odniesieniu do kultury masowej. Tekst ten koncentruje się także na aktualnych próbach zmierzających do „odrodzenia” stoicyzmu, pojmowanego przede wszystkim jako filozofia praktyczna. Autor skupia się na „polskim rynku filozoficznym” i współczesnych propagatorach „uproszczonego stoicyzmu” - bądź też lub „pop-stoicyzmu” - Marcinie Fabjańskim i Tomasz Mazurze, na ich książkach i działalności prowadzonej poza środowiskiem akademickim. Czy ich publikacje i inne formy działalności mogą przybliżyć ludzi do filozofii w ogóle, a zwłaszcza do stoicyzmu?

Słowa kluczowe: filozofia, filozofia praktyczna, stoicyzm, pop-stoicyzm, stoicyzm popularny, filozofia polska, etyka

\section{Zusammenfassung}

Populärer Stoizismus. Neue Chance für praktische Philosophie oder eher Illusion?

Kann Philosophie in unserer übermäßig kommerzialisierten Kultur funktionieren? Ist sie immer noch nötig? Vielleicht ist die Konzentration auf der Lebenskunst (der Kunst, schöner und weiser zu leben) für das „Überleben der Philosophie“ lebensnotwendig, falls sie mehr als eine lebensferne wissenschaftliche Tätigkeit werden soll? Der Artikel verfolgt das Ziel, gewisse Phänomene zu erforschen, die mit dem gesellschaftlichen und kulturellen Funktionieren der Philosophie in der Gegenwart, insbesondere in Bezug auf die Massenkultur, verbunden sind. Der Text konzentriert sich auch auf aktuellen Versuchen, die die „Renaissance“ des Stoizismus in seinem Verständnis als praktische Philosophie anstreben. Der Autor fokussiert auf den 
"philosophischen Markt" in Polen, die aktuellen Verbreiter des „vereinfachten Stoizismus“ (des sog. Pop-Stoizismus), Marcin Fabjanski und Tomasz Mazur, und deren Bücher und Tätigkeit außerhalb des akademischen Milieus. Sind ihre Veröffentlichungen und andere Formen des Wirkens imstande, den Menschen die Philosophie und insbesondere den Stoizismus näherzubringen?

Schlüsselworte: Philosophie, praktische Philosophie, Stoizismus, Pop-Stoizismus, populärer Stoizismus, polnische Philosophie, Ethik

Ins Deutsche übersetzt von Anna Pastuszka

Informacja o autorze:

TOMASZ STEFANIUK, doktor habilitowany, Instytut Filozofii, Uniwersytet Marii Curie-Skłodowskiej w Lublinie; adres do korespondencji: Instytut Filozofii UMCS, Pl. Marii Curie-Skłodowskiej 4, 20-031 Lublin; e-mail: tomasz.stefaniuk@umcs.pl 